\title{
EFFECT OF LIGHT INTENSITY AND GROWTH SUBSTRATUM ON PLANT DEVELOPMENT AND PRODUCTION OF SECONDARY METABOLITES IN Cordia curassavica (JACQ.) ROEM. \& SCHULT ${ }^{1}$
}

\author{
Maria Terezinha Silveira Paulilo², Flávia Simão Lapa² e Miriam de Barcellos Falkenberg³
}

\begin{abstract}
Cordia curassavica (Jacq.) Roem. \& Schult. (Boraginaceae), also referred to as Cordia verbenacea DC, has been traditionally used for medicinal purposes. This study was driven to verify the behavior of the species in similar conditions to its natural environment, such as high light intensity and sandbank soil, and in conditions of low light intensity and fertilized substratum (dystroferric red nitosoil plus earthworm humus). The growth of the plant, the income of leaf crude extracts and, in the alcoholic extract, the number of substances found in thin layer cromatography and the toxicity of the substratum was observed. The results indicated that the growth of the root biomass, stem and leaves in discharge or lower light intensity was similar, but smaller in sandbank soil than in fertilized soil. The relative income of extracts in ether of petroleum and alcohol was larger in high light intensity and fertilized substratum. The light intensity and the substratum type didn't affect the number of substances detected in the alcoholic extract or the toxicity of this extract. Stains corresponding to the rosmarinic acid were only evidenced in some samples of the alcoholic extract, not allowing the verification of the effect of the treatments about its production.
\end{abstract}

Keywords: Light, Substratum and Secondary metabolites

\section{EFEITO DA INTENSIDADE DE LUZ E SUBSTRATO NO CRESCIMENTO DA PLANTA E PRODUÇÃO DE METABÓLITOS SECUNDÁRIOS EM Cordia curassavica (JACQ.) ROEM. \& SCHULT}

\begin{abstract}
RESUMO - Cordia curassavica (Jacq.) Roem. \& Schult. (= Cordia verbenacea DC.), Boraginaceae, tem sido tradicionalmente utilizada com propósitos medicinais. Este estudo verificou o comportamento da espécie em condições similares ao ambiente natural, alta intensidade de luz e solo de restinga e em condição de baixa intensidade de luz e substrato adubado (solo distroférrico mais húmus de minhoca). valiaram-se o crescimento da planta, o rendimento de extratos brutos de folha, o número de substâncias encontradas em cromatografia de placa no extrato alcoólico e a toxicidade do substrato. Os resultados indicaram que o crescimento da biomassa de raiz, de caule e de folhas em alta ou baixa intensidade de luz foi similar, mas menor em solo de restinga que em solo adubado. O rendimento relativo de extratos em éter de petróleo e alcoólico foi maior em alta intensidade de luz e substrato adubado. A intensidade de luz e o tipo de substrato não afetaram o número de substâncias detectadas no extrato alcoólico ou a toxicidade desse extrato. Manchas correspondentes ao ácido rosmarínico foram evidenciadas apenas em algumas amostras de extrato alcoólico, não permitindo a verificação do efeito dos tratamentos sobre sua produção.
\end{abstract}

Palavra-chave: Luz, Substrato e Metabólitos secundários.

\section{INTRODUCTION}

Cordia curassavica (Jacq.) Roem. \& Schult. belongs to the Boraginaceae family and it is found from Central America to southern Brazil, occurring in sandbanks (SMITH, 1970). As most plant species, C. curassavica produces compounds of the secondary metabolism for their ecological relationships. The main ecological functions of the secondary metabolites in plant species is its protection against viral, bacterial and fungi diseases, grazing, attraction or repletion of other organisms and resistance to environmental stresses

\footnotetext{
${ }^{1}$ Recebido em 04.07.2008 e aceito para publicação em 02.03.2010.

${ }^{2}$ Universidade Federal de Santa Catarina, UFSC, Brasil. E-mail: <paulilo@ccb.ufsc.br> e <flavia@yahoo.com.br>.

${ }^{3}$ UNEAGRO/SC, UNEAGRO, Brasil.
} 
(ALMEIDA-CORTEZ, 2003). These secondary metabolites can present medicinal properties for human beings. The alcoholic extract of $C$. curassavica is the main form utilized by the population for disease treatment (SMITH, 1970; AKISUE et al., 1983). Pharmacological and chemical studies have demonstrated the presence of compounds with anti-inflammatory properties in leaves of C. curassavica (CARVALHO Jr. et al., 2004, FERNANDES et al., 2007). Rosmarinic acid, a phenolic secondary metabolite found in at least 14 plant families, presenting antiviral, antibacterial, anti-inflammatory and antioxidant activities (Petersen \& Simmonds, 2003) was isolated from $C$. curassavica, showing specific inhibitory effect on the edema caused by poison of the Bothros jararacussu snake (TICLI et al., 2005). This snake is responsible for the majority of ophidian accidents registered in Brazil (BOCHNER e STRUCHINER, 2003).

The nature and the amount of secondary compounds produced by plant species during its development depends on internal plant factors, as well as environmental factors, which can act directly on the synthesis of the secondary metabolites, or indirectly, increasing or decreasing the biomass of the plants (GOUINGUENÉ e TURLINGS, 2002). Light intensity and substratum fertility can influence the quantity and quality of secondary metabolites (RODRIGUES et al. 2004; VALMORBIDA et al. 2007) and can also increase or decrease plant biomass (ALVARENGA et al., 2003; MORATELLI et al., 2007).

The aim of this study was to investigate the influence of light intensity and substratum fertility in plant growth of $C$. curassavica and in the quantity and quality of secondary metabolites.

\section{MATERIALAND METHODS}

Plant material: Plants of Cordia curassavica (Jacq.) Roem. \& Schult (Figure 1) were produced from seeds supplied by CPQBA (Center for Chemical, Biological and Agronomic Research), UNICAMP, Paulínea - SP. The seeds came from a hundred plants taken at random, cultivated in 12 hectares in CPQBA.

Plant growing conditions and experimental design: The experiments were conducted outdoors, at the campus of the "Federal University of Santa Catarina”, Florianópolis, the state of Santa Catarina, Brazil. For the light treatment, plants in plastic bags (3L) filled with mixed substratum
Photo: Miriam de Barcellos Falkenberg, 2006. Foto: Miriam de Barcellos Falkenberg, 2006.

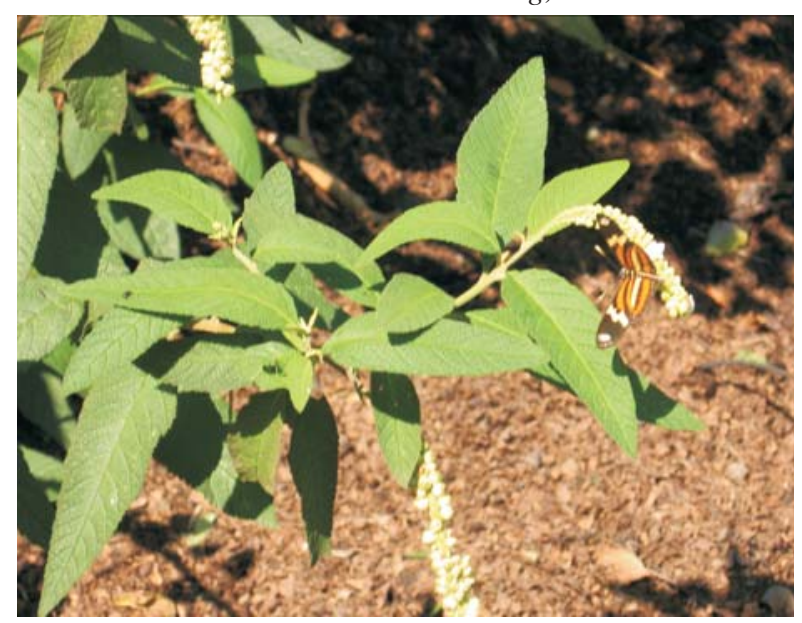

Figure1 - Cordia curassavica (Jacq.) Roem. et Schult. Figura 1 - Cordia curassavica (Jacq.) Roem. et Schult.

(substratum composed of dystroferric red nitosoil and earthworm humus of California, ADUPLAN-CREA061623-6 in the proportion of 1:1) were separated into three different light environments: 100\%, 70\% and 20\% of full sunlight. The light environments were produced by fastening a layer of neutral black polyethylene screens, with different mesh sizes, to the top and sides of wooden frames of $1.0 \times 1.0 \times 1.0 \mathrm{~cm}$ (boxes). For the substratum experiment, the plants, in plastic bags (3L) filled with mixed substratum as describe above or sandy soil from sandbanks, were placed in $100 \%$ full sunlight. The level of Photosynthetic Active Radiation (PAR) of full sun light was mesured by an LI-COR 250 light meter with LI-COR quantum sensors (LI-COR, Lincoln, Neb, USA). The maximum PAR of full sunlight at noon, on a typical summer day, was $1800 \mu \mathrm{mol} \mathrm{m}^{-2} \mathrm{~s}^{-1}$, 70\% light was $1260 \mu \mathrm{mol} \mathrm{m}^{-2} \mathrm{~s}^{-1}$ and $20 \%$ light was $360 \mathrm{mmol} \mathrm{m}^{-2} \mathrm{~s}^{-1}$. The plants were watered every day with tap water. The boxes (three boxes per treatment, with three plants per box) were randomly distributed in an open area. The first harvest was made before the beginning of the treatments and the second, after 72 days of growth for light experiment and after 201 days of the growth for substrata experiment, due to the very low plant growth at sandy soil. Nine plants per treatment were harvested for measurements.

Measurements: The dry mass was determined with a scale after drying the plant material for 72 hours at $80^{\circ} \mathrm{C}$. The leaf area was determined by drawing the 
contour of leaves on paper, which was then cut and weighed and this weight was compared with the weight of $1 \mathrm{~cm}^{2}$ of the same paper. Mean relative growth rate (RGR) and mean leaf area ratio (LAR), were calculated throught the classical growth analysis according to Hunt (1982), using the equations RGR $=\left(\log _{\mathrm{e}} \mathrm{W}_{2}-\log _{\mathrm{e}} \mathrm{W}_{1}\right) /\left(\mathrm{T}_{2}-\mathrm{T}_{1}\right) ; \mathrm{LAR}=\left[\left(\mathrm{L}_{\mathrm{A} 1} / \mathrm{W}_{1}\right)\right.$ $\left.+\left(\mathrm{L}_{\mathrm{A} 2} / \mathrm{W}_{2}\right)\right] / 2$; where $\mathrm{W}$ is plant dry mass, $\mathrm{L}_{\mathrm{A}}$ is leaf area, and $T_{2}-T_{1}$ is the time interval between harvests.

Crude extracts: Leaf tissue was extracted in petroleum ether, chloroform and ethanol (100mg fresh leaf tissue/20ml) for $48 \mathrm{~h}$, forming petroleum ether, chloroform and ethanolic extracts. The extracts were filtered and evaporated to dryness on a rotatory evaporator, between 40 and $60^{\circ} \mathrm{C}$. The remaining dry mass after evaporation of the solvent constituted the crude extract. For the extractions, nine plants, three leaves per plant, for each treatment were utilized, performing nine extracts of each solvent per treatment. The leaves of each plant were cut in little pieces and weighed together. The leaves taken for the extractions corresponded to the last leaves with total expansion.

\section{Analysis of the chemical composition of the ethanolic crude extract and determination of rosmarinic acid: This determination was carried through Thin Layer Chromatography (TLC) developed in plates of silica gel $\mathrm{F}_{254}$, with solution constituted by chloroform, methanol and water (30: 11:2). The nine ethanolic crude extracts per treatment had been suspended again in ethanol $(1: 20 \mathrm{mV})$ and one aliquot of $10 \mu \mathrm{L}$ of each extract had been applied to the TLC plate. A solution of rosmarinic acid was also applied as a chromatographic pattern. After chromatographic migration, the plates were evaluated under ultraviolet light at 365 and $254 \mathrm{~nm}$. The spots that appeared in each of the wave lengths were marked. After that the plates were sprayed with sulphuric anisaldeide and evaluated again under ultraviolet light, marking the spots that had appeared in each one of these wave lengths.}

Evaluation of the toxicity of alchoolic extracts: This was conducted through the bioassay of brine shrimp assay (Artemia salina Leach.), according to Meyer et al. (1982). For toxicity testing, samples of 10 larvae were added to $5 \mathrm{ml}$ of seawater in an assay tube containing the appropriate concentration on extract and maintained for $24 \mathrm{hr}$ in the dark (triplicate). Lethal median concentration (LC50) was calculated.

Statistical Analysis: The comparison between two averages was made through the $t$ test and between three averages, through ANOVA, followed by the Tukey test. To analyze qualitative data from the chromatography the Mann Whitney test was employed, and the results compared 2X2 (100\% with 70\% and 100\% with 20\%). The analyses were done using the computational program Statisoft (STATISOFT, 2005). The data from the brine shrimp assay was analyzed with the qui-square test, with contingency table 2X2, and the Yates correction, using the computational program Probit (USEPA, 2005).

\section{RESULTS AND DISCUSSION}

Influence of light intensity and substratum on plant growth: The data presented in table 1 show that the plant growth in biomass was not affected by the light intensity tested, representing the maximum PAR of $360 \mathrm{mmol} \mathrm{m}^{-2} \mathrm{~s}^{-1}, 1260 \mathrm{mmol} \mathrm{m}^{-2} \mathrm{~s}^{-1}$ and $1800 \mathrm{mmol} \mathrm{m}^{-2} \mathrm{~s}^{-1}$. This response can indicate that the light photosynthetic saturation point for the plants at the experimental conditions was similar or lower than the minimum light treatment applied $\left(360 \mathrm{mmol} \mathrm{m}^{-2} \mathrm{~s}^{-1}\right)$. Another possibility could be the shortage of nutrients for 72 days of growth under higher light, but this possibility is unlikely to occur, since between 72 and 201 days of growing the plants showed an increment in biomass.

Despite the occurrence of the species in sunny areas, such as sandbank regions, some plasticity to adjust to the shadow condition was verified in the plants, when compared to plants under $100 \%$ and $20 \%$ light intensity, as the decrease in root/ shoot ratio and increase in LAR, alterations which favor light absorption (POORTER, 1999). Although C. curassavica occurs in infertile habitats, such as sandbanks, dunes and beaches (MONTANARI, 2000), its plants were capable of profiting from the nutritional increase offered by the mixed substratum, which resulted in plants with higher biomass and greater RGR values than plants grown in sandy soil (table 1). This result is in accordance with Montanari (2000), which had observed greater development of C. curassavica in more fertile substratum. 
Table 1 - Dry mass, mean relative growth rate (RGR), mean leaf area rate (LAR) and root/shoot ratio (R/S) of Cordia curassavica plants grown at three light regimes for 72 days and two nutritional regimes for 201 days.

Tabela 1 - Massa seca, taxa média de crescimento relativo (RGR), taxa média de área foliar (LAR) e razão raiz/parte aérea (R/S) de plantas de Cordia curassavica crescidas em três regimes de luz por 72 dias e dois regimes nutricionais por 201 dias.

\begin{tabular}{|c|c|c|c|c|c|c|}
\hline $\begin{array}{l}\text { Light } \\
\text { intensity }\end{array}$ & Leaf(g) & Shoot (g) & Root(g) & RGR( g g $^{-1}$. day $\left.{ }^{-1}\right)$ & $\operatorname{LAR}\left(\mathrm{cm}^{2} \cdot \mathrm{g}^{-1}\right)$ & $\mathrm{R} / \mathrm{S}$ \\
\hline $100 \%$ & $2.48 a( \pm 0.74)$ & $3.60 \mathrm{a}( \pm 1.11)$ & $1.43 a( \pm 0.49)$ & $0.056 \mathrm{a}( \pm 0.004)$ & $208.52 \mathrm{~b}( \pm 5.06)$ & $0.40 \mathrm{ab}( \pm 0.07)$ \\
\hline $70 \%$ & $2.59 \mathrm{a}( \pm 0.84)$ & $2.67 \mathrm{a}( \pm 1.91)$ & $1.20 \mathrm{a}( \pm 0.53)$ & $0.056 \mathrm{a}( \pm 0.005)$ & $225.25 b( \pm 14.35)$ & $0.50 \mathrm{a}( \pm 0.29)$ \\
\hline $20 \%$ & $2.25 a( \pm 0.71)$ & $3.47 \mathrm{a}( \pm 1.20)$ & $0.78 a( \pm 0.38)$ & $0.054 \mathrm{a}( \pm 0.006)$ & $254.38 \mathrm{a}( \pm 22.47)$ & $0.20 \mathrm{~b}( \pm 0.09)$ \\
\hline Substrata type & & & & & & \\
\hline $\begin{array}{l}\text { Mixed } \\
\text { substratum }\end{array}$ & $4.37 \mathrm{~A}( \pm 1.95)$ & $8.35 \mathrm{~A}( \pm 3.63)$ & $4.38 \mathrm{~A}( \pm 1.29)$ & $0.034 \mathrm{~A}( \pm 0.003)$ & $187.65 \mathrm{~B}( \pm 5.85)$ & $0.56 \mathrm{~A}( \pm 0.17)$ \\
\hline Sandbank soil & $0.95 \mathrm{~B}( \pm 0.72)$ & $1.45 \mathrm{~B}( \pm 1.01)$ & $0.82 \mathrm{~B}( \pm 0.38)$ & $0.025 \mathrm{~B}( \pm 0.003)$ & $195.05 \mathrm{~A}( \pm 8.66)$ & $0.67 \mathrm{~A}( \pm 0.33)$ \\
\hline
\end{tabular}

Letters compare vertical values. Small letters compare different light intensities and capital letters, different substrata. Values followed by the same letter don't differ amongst themselves $(\mathrm{p} \leq 0.05)$. Data between parentheses show the standard deviation. 20\% light intensity $=360 \mu \mathrm{mol} \mathrm{m}^{-2} \mathrm{~s}^{-1}, 70 \%$ light intensity $=1260 \mu \mathrm{mol} \mathrm{m} \mathrm{m}^{-2} \mathrm{~s}^{-1}$ and $100 \%$ light intensity $=1800 \mu \mathrm{mol} \mathrm{m}{ }^{-2} \mathrm{~s}^{-1}$.

\section{Influence of light intensity and substratum in crude extract relative yield}

The relative yield of petroleum ether and ethanolic extracts was higher in full sun plants and mixed substratum (table 2). The light and the mixed substratum seem to aid the production of lipophilic substances, which are more soluble in non polar solvents such as petroleum ether, and of hydrophilic substances soluble in ethanol, such as phenolic compounds (FALKENBERG et al., 2003). The relative yield of chloroform extracts didn't present differences in the light intensity and substratum type (table 2), probably because the substances that could be extracted in chloroform already would have been extracted in petroleum ether, since the two solvents extract non polar substances.
The Plants grown for 201 days had greater relative yield of crude extracts than 72 day old plants, suggesting that at 201 days the plants were close to budding, an event that normally leads to an increase of secondary compound production (MONTANARI, 2000).

\section{Influence of light intensity and substratum on production of rosmarinic acid and other substances extracted by ethanol.}

Unfortunately it wasn't possible to verify the influence of the treatments on the quantity of rosmarinic acid, since the ethanolic extract of plants, applied on TLC plates, did not show significant presence of rosmarinic acid. Only four of 18 samples from $100 \%$ light grown plants (three for fertile substratum and one for infertile substratum) and only two of nine samples from $70 \%$ light grown plants, presented spots that,

Table 2 - Relative yield of crude extracts of Cordia curassavica plants grown at three light regimes for 72 days and two nutritional regimes for 201 days.

Tabela 2 - Rendimento relativo de extratos brutos de plantas de Cordia curassavica crescidas em três regimes de luz por 72 dias e dois regimes nutricionais por 201 dias.

\begin{tabular}{|c|c|c|c|c|}
\hline Treatments & $\begin{array}{c}\text { Chloroformic extract } \\
\text { (g /100 g tissue) }\end{array}$ & $\begin{array}{l}\text { Petroleum ether extract } \\
\text { (g /100 g tissue) }\end{array}$ & $\begin{array}{l}\text { Ethanolic extract } \\
\text { (g /100 g tissue) }\end{array}$ & $\begin{array}{c}\text { Total } \\
\text { (g /100 g tissue) }\end{array}$ \\
\hline $100 \%$ light & $0.59 \mathrm{a}( \pm 0.47)$ & $3.17 \mathrm{a}( \pm 0.89)$ & $2.36 \mathrm{a}( \pm 0.96)$ & $6.12 \mathrm{a}( \pm 1.00)$ \\
\hline $70 \%$ light & $0.45 \mathrm{a}( \pm 0.14)$ & $1.61 \mathrm{~b}( \pm 0.99)$ & $2.20 \mathrm{a}( \pm 0.26)$ & $4.26 \mathrm{~b}( \pm 0.78)$ \\
\hline $20 \%$ light & $0.51 \mathrm{a}( \pm 0.18)$ & $1.28 \mathrm{~b}( \pm 0.76)$ & $0.77 \mathrm{~b}( \pm 0.31)$ & $2.56 \mathrm{c}( \pm 0.70)$ \\
\hline Substrata type & & & & \\
\hline Mixed substratum & $1.24 \mathrm{~A}( \pm 0.15)$ & $4.0 \mathrm{~A}( \pm 1.11)$ & $8.15 \mathrm{~A}( \pm 1.74)$ & $13.69 \mathrm{~A}( \pm 2.83)$ \\
\hline Sandybank soil & $0.79 \mathrm{~A}( \pm 0.65)$ & $2.5 \mathrm{~B}( \pm 1.71)$ & $5.04 \mathrm{~B}( \pm 2.08)$ & $8.00 \mathrm{~B}( \pm 2.69)$ \\
\hline
\end{tabular}

Letters compare vertical values. Small letters compare different light intensities and capital letters, different substrata. Values followed by the same letter don't differ amongst themselves $(\mathrm{p} \leq 0.05)$ Data between parentheses show the standard deviation.

Letras comparam valores na vertical. letras pequenas comparar diferentes intensidades de luz e maiúsculas, diferentes substratos. Valores seguidos pela mesma letra não diferem entre si $(p \leq 0,05)$ Dados entre parênteses indicam o desvio padrão.

Revista Árvore, Viçosa-MG, v.34, n.3, p.417-423, 2010 
for the chromatographic behavior, could correspond to the rosmarinic acid. This lack of uniformity in the results could be explained by the plant-to-plant variability of rosmarinic acid content (SHETTY, 2001).

The average number of substances detected in TLC plate was not significantly different between treatments (table 3) possibly due to the high heterogeneity in the number of metabolites detected through TLC in plants with the same treatment, which resulted in high standard deviations within a single treatment line. These heterogeneities, as discussed above, could be explained by the plant-to-plant variability (SHETTY, 2001; FIGUEIRA et al., 2001).

\section{Toxicity of the ethanolic extract on brine shrimp assay}

Several works try to correlate the toxicity of plant extract on Artemia salina with antifungal, antimicrobial, antiviral, antiparasitary, trypanosomicide and antitumoral activities (SIQUEIRA et al., 1998). Ethanolic extracts of $C$. curassavica leaves proved to be toxic for Artemia salina larvae (figures 2 e 3). However, this toxicity appeared not to be influenced by the light intensity or by the fertility of the substratum of growing plants. The results suggest that the toxicity is not related to the relative yield of the extract, since the relative yield of the ethanolic extract of plants grown was influenced by light intensity and substratum fertility.

Table 3 - Number of stains for ethanolic extracts sample detected in the thin layer cromatography from Cordia curassavica plants grown at three light intensities for 72 days and two substrata for 201 days.

Tabela 3 - Número de mancas em amostras do extrato etanólico detectadas em cromatografia de camada delgada de plantas de Cordia curassavica crescidas em três regimes de luz por 72 dias e dois regimes nutricionais por 201 dias.

\begin{tabular}{|c|c|c|c|c|c|}
\hline \multirow{2}{*}{$\begin{array}{c}\text { Treatments } \\
\text { Samples } \\
\end{array}$} & $100 \%$ light & $70 \%$ light & $20 \%$ light & Mixed substratum & Sandbank soil \\
\hline & \multicolumn{5}{|c|}{ Number of stains } \\
\hline 1 & 7 & 7 & 1 & 3 & 3 \\
\hline 2 & 2 & 8 & 3 & 7 & 6 \\
\hline 3 & 6 & 4 & 3 & 9 & 2 \\
\hline 4 & 7 & 2 & 5 & 1 & 3 \\
\hline 5 & 7 & 2 & 6 & 9 & 3 \\
\hline 6 & 4 & 7 & 1 & 8 & 6 \\
\hline 7 & 2 & 3 & 1 & 2 & 7 \\
\hline 8 & 3 & 4 & 2 & 6 & 6 \\
\hline 9 & 7 & 5 & - & 5 & 3 \\
\hline Medium & 5.0 а $( \pm 2.24)$ & $4.67 \mathrm{a}( \pm 2.24)$ & 2.75 a $( \pm 1.91)$ & $5.56 \mathrm{~A}( \pm 3.00)$ & $4.33 \mathrm{~A}( \pm 1.87)$ \\
\hline
\end{tabular}

Letters compare horizontal values. Small letters compare different light intensities and capital letters, different substrata. Values followed by the same letter don't differ amongst themselves $(\mathrm{p} \leq 0.05)$. Data between parentheses show the standard deviation. Cartas comparar os valores horizontal. letras pequenas comparar diferentes intensidades de luz e maiúsculas, diferentes substratos. Valores seguidos pela mesma letra não diferem entre si $(p \leq 0,05)$. Dados entre parênteses indicam o desvio padrão.

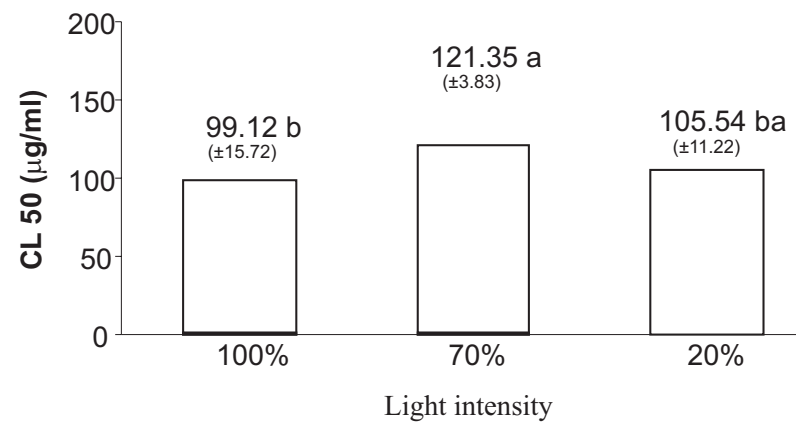

Figure 2 - Medium lethal concentration (CL50) of ethanolic extracts from Cordia curassavica plants grown at three light regimes. Letters compare treatments. Values followed by the same letter don't differ.

Figura 2 - Concentração letal média (CL50) de extratos etanólicos de plantas de Cordia curassavica crescidas em três regimes de luz. Letras comparam tratamentos. Valores seguidos pela mesma letra não diferem entre si.

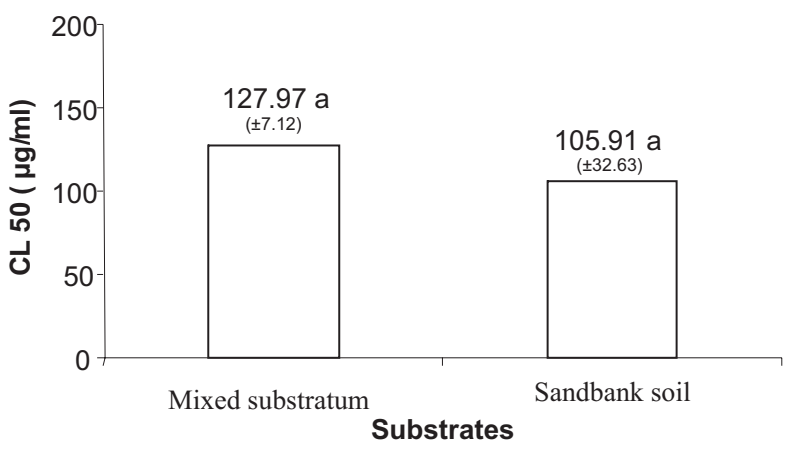

Figure 3 - Medium lethal concentration (CL50) of ethanolic extracts from Cordia curassavica plants grown in soil and sand. Letters compare treatments. Values followed by the same letter don't differ.

Figura 3 - Concentração letal média (CL50) de extratos etanólicos de plantas de Cordia curassavica crescidas em solo e areia. Letras comparam tratamentos. Valores seguidos pela mesma letra não diferem entre si.

Revista Árvore, Viçosa-MG, v.34, n.3, p.417-423, 2010 


\section{CONCLUSION}

High light and substratum fertility affected the relative secondary metabolite yield production in $C$. curassavica. Leaf biomass production was not affected by light variation, but was by substratum fertility.

\section{REFERENCES}

ALMEIDA-CORTEZ, J. S.; SHIPLEY, B.; ARNASON, J. T. Effects of nutrient availability on the production of pentaynene, a secondary compound related to defense, in Rudbeckia hirat . Plant Species Biology, v.18, v.1, p.85-89, 2003.

ALVARENGA, A. A. et al. Efeito de diferentes níveis de radiação sobre o crescimento inicial e fotossíntese de plantas de Croton urucurana Baill. na região sudeste do Brasil. Revista Árvore, v.27, n.1, p.53-57, 2003.

AKISUE, M. K. et al. Caracterização farmacognóstica da droga e da tintura de Cordia verbenacea A. DC.- BORAGINACEAE. Revista de Ciências Farmacêuticas, v.5, n.1, p.69-82, 1983.

BOCHNER, R.; STRUCHINER, C. J. Epidemiologia dos acidentes ofídicos nos últimos 100 anos no Brasil: uma revisão. Cadernos de Saúde Pública, v.19, n.1, p.7-16, 2003.

CARVALHO, J. R. et al. Chemical composition and antimicrobial activity of the essential oil of Cordia verbenacea DC. Journal of Ethnopharmacology, v.95, n. 2-3, p.297-301, 2004.

FALKENBERG, M. B.; SANTOS, R. I.; SIMÕES, C. M. O. Introdução à análise fitoquímica. In: SIMÕES C. M. O. et al., (Eds.)

Farmacognosia: da planta ao medicamento 5.ed. Porto Alegre/Florianópolis: Universidade Federal do Rio Grande do Sul/Universidade Federal de Santa Catarina, 2003. p.229-245.

FERNANDES, E. S. et al. Anti-inflammatory effects of compounds alpha-humulene and (")trans-caryophyllene isolated from the essential oil of Cordia verbenacea. European

Journal of Pharmacology, v.569, n.3, p.228-236, 2007.

Revista Árvore, Viçosa-MG, v.34, n.3, p.417-423, 2010
FIGUEIRA, G. M. et al. Características morfológicas, fitoquímicas de Cordia curassavica e estudo da propagação in vitro. In: SIMPÓSIO DE RECURSOS GENÉTICOS PARAAAMÉRICA LATINA E CARIBE, 3., 2001, Londrina.

Anais...Londrina: Instituto Agronômico do Paraná, 2001. p.295-297.

GOUINGUENÉ, S. P.; TURLINGS, T. C. J. The effects of abiotic factors on induced volatile emissions in corn plants. Plant Physiology, v.129, p.1296-1307, 2002.

HUNT, R. Plant growth curves the functional approach to plant growth analysis. London: Edward Arnold, 1982. 248p.

MEYER, B. N. et al. Brine Shrimp: a convenient general bioassay for active plant constituents. Planta Medica, v.45, n.1, p.31-34, 1982.

MONTANARI Jr., I. Cultivo comercial de ervabaleeira. Revista Agroecologia Hoje, v.3, n.1, p. 14-15, 2000.

MORATELLI, E. M. et al. Efeito da disponibilidade de água e de luz na colonização micorrízica e no crescimento de Tabebuia avellanedae Lorentz ex Griseb. (BIGNONIACEAE). Revista Árvore, v. 31, n.3, p.555-566, 2007.

PETERSEN, M.; SIMMONDS, M. S. J. Rosmarinic acid. Phytochemistry, v.62, no2, p.121-125, 2003.

POORTER, L. Growth responses of 15 rainforest tree species to a light gradient: the relative importance of morphological and physiological traits. Functional Ecology, v.13, p.396-410, 1999.

SIQUEIRA J. M. et al. Estudo fitoquímico de Unonopsis lindimanii, biomonitorado pelo ensaio de toxicidade sobre a Artemia salina. Química Nova, v.21, n.5, p.557-559, 1998.

STATISOFT. Inc. STATISTICA (data analysis software system), version 6 . Available at: < http:// www.statsoft.com >. Accessed on: 15 Aug. de 2005.

USEPA. Software Probit Analysis

Program v.1.5 (probit.exe). Available at: <http: www.agls.uidaho.edu/etoxiweb/resources/ resources.htm>. Accessed on: 15 Aug. 2005. 
SÁNCHEZ, J. E. Cordia subgénero Varronia (Boraginaceae). Flora de Colômbia, v.14, n.1, p.1-176, 1995.

SHETTY, K. Biosynthesis and medical applications of rosmarinic acid. Journal of Herbs, Spices \& Medicinal Plants, v.8, n.2-3, p.161-181, 2001.

SMITH, L. B. Boragináceas. In: REITZ, R. Flora ilustrada Catarinense. Itajaí: Herbário Barbosa Rodrigues, 1970. p.19-20.

SILVA, M. A. S. et al. Composição e teor do óleo essencial de duas variedades de Guaçatonga do cerrado e mata. In: CONGRESSO BRASILEIRO DE OLERICULTURA, 44., 2004, Campo Grande.

Anais... Campo Grande: 2004.
SKOULA, M.; ABBES, J. E.; JOHNSON, C. B. Genetic variation of volatiles and rosmarinic acid in populations of Salvia fruticosa mill growing in Crete. Biochemical Systematics and Ecology, v.28, n.6, p.551-561, 2000.

TICLI, F. K. et al. Rosmarinic acid, a new snake venom phospholipase A2 inhibitor from Cordia verbenacea (Boraginaceae): anriserum action potentiation and molecular interaction. Toxicon, v.46, nº.3, p.318-327, 2005.

VALMORBIDA, J.; BOARO, C. S. F. Growth and development of Mentha piperita L. in nutrient solution as affected by rates of potassium.

Brazilian Archives of Biology and Technology, v.50, n.3, p.379-384, 2007. 